\title{
18. PRELIMINARY LIPID ANALYSES OF CORES 49, 54, AND 59 FROM HOLE $462^{1}$
}

\author{
I. D. Thomson, S. C. Brassell, P. A. Comet, G. Eglinton, P. J. Isaacson, J. McEvoy, and J. R. Maxwell,
} Organic Geochemistry Unit, University of Bristol, School of Chemistry, Cantock's Close, Bristol BS8 1TS, U.K.

\begin{abstract}
The solvent-extractable lipids of Sections 462-49-4 (lower Maestrichtian), 462-54-2 (Campanian), and 462-59-1 (Cenomanian), from the Nauru Basin, were investigated for aliphatic and aromatic hydrocarbons, ketones, alcohols, and acids, after separation into acid and neutral fractions. Detailed analyses of the total neutral fraction revealed only $n$-alkanes, steranes, and triterpanes present in sufficient concentration ( $>0.5 \mathrm{ng} / 100 \mathrm{~g}$ dry sediment for individual compounds) for component recognition. $N$-alkanes $\left(\mathrm{C}_{19}-\mathrm{C}_{35}\right)$ constitute the major component of each section, with the most abundant present as $10\left(n-\mathrm{C}_{24}\right), 135\left(n-\mathrm{C}_{29}\right), 17\left(n-\mathrm{C}_{26}\right) \mathrm{ng} / 100 \mathrm{~g}$ dry sediment in Sections 462-49-4, 462-54-2, and 462-59-1, respectively.

The results suggest a high degree of thermal maturity of the lipids, which is interpreted in terms of the high geothermal gradient (about $50^{\circ} \mathrm{C} / \mathrm{km}$ ) and the regional volcanicity. The lipid data also suggest that the major source of organic matter was terrestrial and that deposition took place in a low-productivity oxic environment.
\end{abstract}

\section{INTRODUCTION}

The compositions of lipid components from material collected at Site 462 of the Nauru Basin, drilled during Leg 61, have been determined. Three sections have been investigated, by analysis of their extractable lipid components, as two fractions: (1) neutrals (treated with BSTFA to silylate alcohols) and (2) acids as methyl esters (FAME). All sections were low in content of extractable lipids; only $n$-alkanes, steranes, and triterpanes were detected in sufficient quantities $(>0.5$ $\mathrm{ng} / 100 \mathrm{~g}$ dry sediment) for component recognition.

Table 1 summarizes the lithologic characteristics of cores adjacent to those investigated, and includes dry extracted weights of the samples.

The results are interpreted in an attempt to describe the relationships between the maturity of the sediments and the geological framework. The possibility of pipe dope contamination is also discussed.

\section{EXPERIMENTAL METHODS}

The basic experimental scheme for sample analyses and control analyses performed in parallel is shown in Figure 1. It differs from our previous analyses (Barnes et al., 1979; Brassell, Comet, 1980b), in that the small amounts of extractable lipids present, as shown by gas chromatography (GC), precluded subsequent fractionation of the "neutral" fraction by thin-layer chromatography.

GC was performed on a Carlo Erba 2150 gas chromatograph equipped with a $20 \mathrm{~m} \mathrm{OV}-1$ glass capillary column $(0.25 \mathrm{~mm}$ i.d. $)$ and $\mathrm{He}$ as a carrier gas. The instrument was temperature-programmed at $4^{\circ} \mathrm{min}^{-1}$ from 50 to $275^{\circ} \mathrm{C}$, followed by up to 30 minutes isothermal running.

Mass spectra were recorded using a Finnigan 4000 gas chromatograph-mass spectrometer (GC-MS) system equipped with a $20 \mathrm{~m} \mathrm{OV}-1$ glass capillary column. Data acquisition and processing were controlled by an INCOS 2300 data system. Typical operating conditions were as follows: ion-source temperature, $250^{\circ} \mathrm{C}$; electron energy, $35 \mathrm{eV}$; filament current, $350 \mu \mathrm{A}$; scan $(\mathrm{m} / z 50-500)$ time, 1 second. The organic carbon values shown in Table 1 were obtained on a PerkinElmer $240 \mathrm{CHN}$ analyzer.

\footnotetext{
${ }^{1}$ Initial Reports of the Deep Sea Drilling Project, Volume 61
}

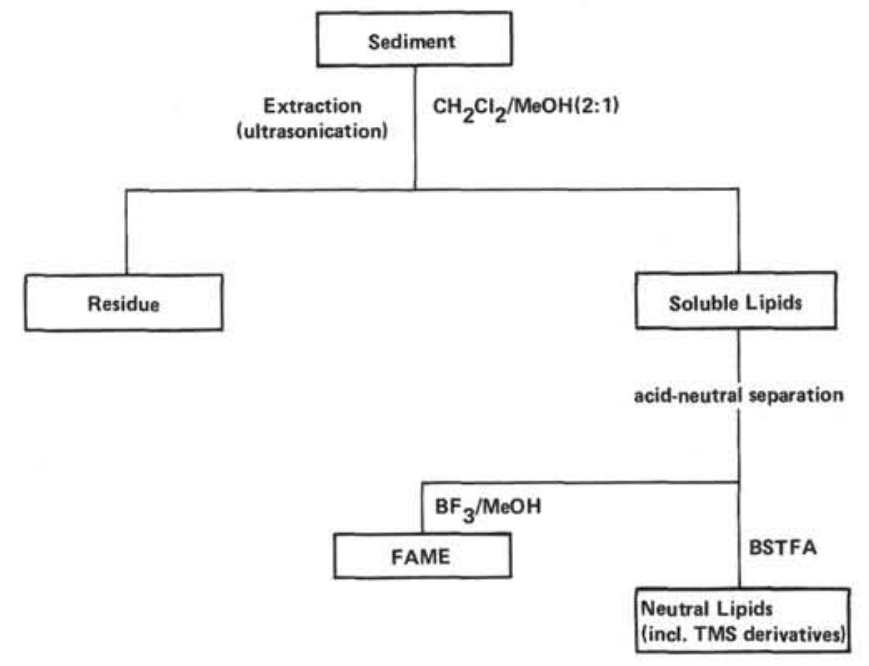

Figure 1. Experimental scheme.

\section{RESULTS}

\section{General}

Inspection of the sediment cores before extraction revealed no visible pipe dope or other shipboard oilbased contamination. Control analyses performed in parallel with sample analyses did not produce detectable amounts of lipid material at similar GC injection volumes.

No alcohols, ketones, or unsaturated hydrocarbons were detected in the neutral lipids by exhaustive mass fragmentographic (MF) searches using key ions (see Brassell, Comet, et al., 1980b; and Brassell, Gowar, et al., in press); only alkanes were detected in all sections. All samples exhibited a "hump" in the GC trace (e.g., Brassell and Eglinton, in press) of the neutral fraction (see Fig. 2). No aromatic hydrocarbons were detected (hence, $<0.5 \mathrm{ng} / 100 \mathrm{~g}$ dry sediment), although this may reflect the expected low concentrations of these compounds. No lipids were detected in the "acid" (FAME) 
Table 1. Hole 462: Samples studied.

\begin{tabular}{cccccc}
\hline $\begin{array}{c}\text { Core-Section, Interval } \\
(\mathrm{cm})^{\mathrm{a}}\end{array}$ & $\begin{array}{c}\text { Depth } \\
\text { Sub-bottom } \\
(\mathrm{m})\end{array}$ & $\begin{array}{c}\text { Chronostratigraphy } \\
\text { and Ageb } \\
(\mathrm{m} . \mathrm{y} .)\end{array}$ & $\begin{array}{c}\text { Lithologyb } \\
\text { (nearest described sample) }\end{array}$ & $\begin{array}{c}\text { Dry } \\
\text { Weight } \\
(\mathrm{g})\end{array}$ & $\begin{array}{c}\text { Total } \\
\text { Organic } \\
\text { Carbon } \\
(\%)\end{array}$ \\
\hline $49-4,125-150$ & 462 & $\begin{array}{l}\text { Lower } \\
\text { Maestrichtian } \\
(\sim 70)\end{array}$ & $\begin{array}{l}\text { Greenish gray nannofossil } \\
\text { marl (49-1, 90) }\end{array}$ & 232 & 0.11 \\
$54-2,120-140$ & 512 & $\begin{array}{l}\text { Campanian } \\
(\sim 75)\end{array}$ & $\begin{array}{l}\text { Light, olive-gray limestone } \\
(54-1,148)\end{array}$ & 180 & 0.04 \\
$59-1,130-150$ & 551 & $\begin{array}{l}\text { Cenomanian } \\
(\sim 90)\end{array}$ & $\begin{array}{l}\text { Pale brown zeolitic } \\
\text { marlstone }(59-1,94)\end{array}$ & 154 & 0.05 \\
\hline
\end{tabular}

a Section 462-59-1 collected without a core liner.

b Site Report, this volume. The sample lithologies were not described on ship and may differ from those quoted here.

fraction of any section by GC analyses (detection limit about $0.2 \mathrm{ng} / 100 \mathrm{~g}$ ).

\section{Acyclic Components}

$\mathrm{N}$-alkanes are the major compound class of each section, ranging from $\mathrm{C}_{20}-\mathrm{C}_{31}, \mathrm{C}_{19}-\mathrm{C}_{35}$, and $\mathrm{C}_{19}-\mathrm{C}_{35}$ in Sections 462-49-4, 462-54-2, and 462-59-1, respectively. Their distributions and concentrations (ng/100 g dry sediment) in each section, calculated from GC response, are shown in Figure 3. All samples exhibit a small oddover-even predominance for their longer-chain $n$-alkanes. Homologues of lower carbon number $\left(<C_{19}\right)$ were not detected in any section.

No acyclic isoprenoid or simple branched-chain alkanes were detected by MF searches of $m / z 85$.

\section{Cyclic Components}

Steranes and disasteranes were detected as minor components in all sections. The small quantities (major component $<0.5 \mathrm{ng} / 100 \mathrm{~g}$ dry sediment) in Sections 462-49-4 and 462-59-1, however, precluded characterization of individual compounds. No 4-methyl steroidal hydrocarbons were detected (hence, $<0.2 \mathrm{ng} / 100 \mathrm{~g}$ dry sediment).

The major steranes and diasteranes of Section 462 $54-2$, characterized by MF $(m / z 217, m / z 259)$, mass spectral interpretation, and GC retention time, are listed in Table 2. A partial MF of $m / z 217$ is shown in Figure 4. Characterization of individual compounds by GCMS co-injection was precluded by the limited amount of

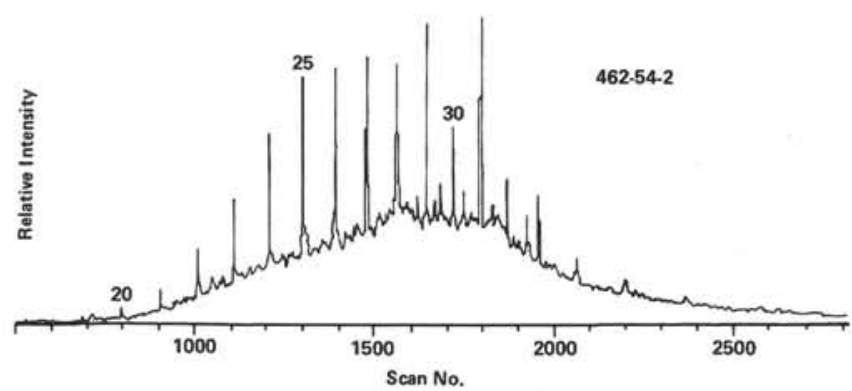

Figure 2. Reconstructed Ion Chromatogram (R.I.C., $m / z 50-500$ ) of total neutral lipids of Section 462-54-2. Peak numbers correspond to $n$-alkane carbon numbers (C-GC-MS conditions in "Experimental Methods," this chapter).
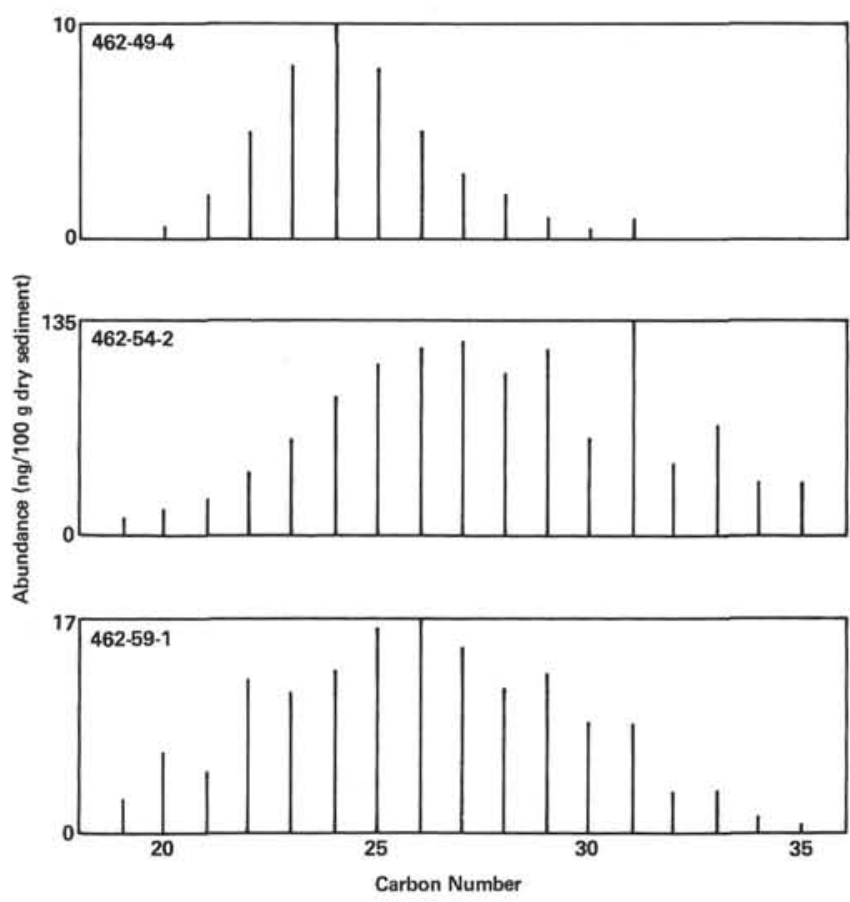

Figure 3. Distribution and abundance of $n$-alkanes in Sections 462 $49-4,462-54-2$, and $462-59-1$.

lipid extract. The $\mathrm{m} / \mathrm{z} 217$ response of assigned components in Figure 4 may be slightly enhanced owing to coelution of minor components; $13 \beta, 17 \alpha$-diasteranes, as both $20 \mathrm{R}$ and $20 \mathrm{~S}$ diastereoisomers, are the dominant steroidal hydrocarbons present. Minor $13 \alpha, 17 \beta$-diasteranes are also present. Identification of individual steranes was complicated by GC coelution with other components and by the low intensity of the mass spectra obtained. Those steranes recognized, however, are tentatively assigned as series of $\mathrm{C}_{27}$ to $\mathrm{C}_{29} 20 \mathrm{R}$ and $20 \mathrm{~S} 5 \alpha$, $14 \alpha, 17 \alpha$-steranes $(\mathrm{m} / z 149 \gg \mathrm{m} / z 151)$ and $20 R$ and $20 S 5 \alpha, 14 \beta, 17 \beta$-steranes $(m / z 218>m / z 217)$ (e.g., Seifert and Moldowan, 1978).

Figure 5 shows the distribution (quantitated from $\mathrm{m} / \mathrm{z} 191$ ) of hopanes that were recognized by their mass spectra, MF of key ions $(m / z 149, m / z 177, m / z 191$, $\mathrm{m} / \mathrm{z} 205, \mathrm{~m} / \mathrm{z} 219, \mathrm{~m} / \mathrm{z} 233, \mathrm{~m} / \mathrm{z} 247$, and $\mathrm{m} / \mathrm{z} 263$ ), and GC retention times. The $\mathrm{C}_{29}-\mathrm{C}_{35}$ hopanes were assigned as $17 \alpha, 21 \beta$-stereoisomers on the basis of their 
Table 2. Steranes and diasteranes of Section 462-54-2.

\begin{tabular}{|c|c|c|c|}
\hline Component $\mathrm{t}^{\mathrm{a}}$ & $\begin{array}{l}\text { Carbon } \\
\text { number }\end{array}$ & Assignment $^{\mathrm{b}}$ & Structure ${ }^{c}$ \\
\hline A & 27 & $20 S 13 \beta, 17 \alpha$-diacholestane & I, $R=H$ \\
\hline B & 27 & $20 R 13 \beta, 17 \alpha$-diacholestane & $\mathrm{I}, \mathrm{R}=\mathrm{H}$ \\
\hline C & 27 & $20 S 13 \alpha, 17 \beta$-diacholestane & II, $\mathrm{R}=\mathrm{H}$ \\
\hline E & 27 & $20 R \quad 13 \alpha, 17 \beta$-diacholestane & II, $\mathbf{R}=\mathbf{H}$ \\
\hline $\mathrm{F}$ & 28 & $20 S$ 24-methyl- $13 \beta, 17 \alpha$-dicholestane & $\mathrm{I}, \mathrm{R}=\mathrm{CH}_{3}$ \\
\hline G & 28 & 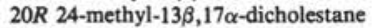 & $\mathrm{I}, \mathrm{R}=\mathrm{CH}_{3}$ \\
\hline $\mathrm{H}$ & 27 & $20 S 5 \alpha, 14 \alpha, 17 \alpha$-cholestane & III, $\mathbf{R}=\mathbf{H}$ \\
\hline 1 & 29 & $20 S$ 24-ethyl-13 $\beta, 17 \alpha$-diacholestane & I, $\mathrm{R}=\mathrm{C}_{2} \mathrm{H}_{5}$ \\
\hline J & 27 & $20 R 5 \alpha, 14 \alpha, 17 \alpha$-cholestane & III, $\mathbf{R}=\mathbf{H}$ \\
\hline $\mathrm{K}$ & 29 & $20 R 24$-ethyl-13 $\beta, 17 \alpha$-diacholestane & $\mathrm{I}, \mathrm{R}=\mathrm{C}_{2} \mathrm{H}_{5}$ \\
\hline L & 28 & $20 R$ 24-methyl- $5 \alpha, 14 \beta, 17 \beta$-cholestane & IV, $\mathrm{R}=\mathrm{CH}_{3}$ \\
\hline M & 28 & 20S 24 -methyl- $5 \alpha, 14 \beta, 17 \beta$-cholestane & IV, $\mathrm{R}=\mathrm{CH}_{3}$ \\
\hline $\mathrm{N}$ & 28 & Unknown & \\
\hline o & 28 & $20 R 24$-methyl-5 $\alpha, 14 \alpha, 17 \alpha$-cholestane & III, $\mathrm{R}=\mathrm{CH}_{3}$ \\
\hline $\mathrm{P}$ & 29 & $20 S$ 24-ethyl-5 $\alpha, 14 \alpha, 17 \alpha$-cholestane & III, $\mathrm{R}=\mathrm{C}_{2} \mathrm{H}_{5}$ \\
\hline Q & 29 & $20 R 24$-ethyl- $5 \alpha, 14 \beta, 17 \beta$-cholestane & IV, $\mathrm{R}=\mathrm{C}_{2} \mathrm{H}_{5}$ \\
\hline $\mathbf{R}$ & 29 & $20 S$ 24-ethyl-5 $\alpha, 14 \beta, 17 \beta$-cholestane & $\mathrm{IV}, \mathrm{R}=\mathrm{C}_{2} \mathrm{H}_{5}$ \\
\hline $\mathbf{S}$ & 29 & $20 R$ 24-ethyl-5 $\alpha, 14 \alpha, 17 \alpha$-cholestane & III, $\mathrm{R}=\mathrm{C}_{2} \mathrm{H}_{5}$ \\
\hline
\end{tabular}

a See Figure 4

b Based on mass spectral interpretation and relative GC retention time (see text; C-24 stereochemistry not determined).

c See appendix, this chapter.

ion ratios (e.g., Wardroper, et al., 1977). The $22 \mathrm{R}$ and $22 \mathrm{~S}$ stereochemistry was assigned by relative GC retention times, 22S eluting before 22R (e.g., Seifert and Moldowan, 1979). No marked difference is apparent in the distribution of those hopanes common to all sections. Failure to detect extended hopanes with higher carbon numbers $\left(>C_{32},>C_{31}\right)$ in Sections 462-49-4 and 462-59-1, respectively, may reflect the smaller quantities of extractable lipids present in these samples.

\section{DISCUSSION}

\section{General}

There appears to be little correlation between the organic carbon content and the amounts of extractable lipids from the three samples; this may reflect differences in kerogen content.

\section{Possibility of Pipe Dope Contamination}

Analyses of Leg 59 samples of low organic-carbon content from the South Philippine Sea have indicated the need to consider pipe-dope contamination as a possibility in such samples (Brassell and Eglinton, in press). Although no evidence of pipe dope was visible in the Site 462 samples, little contamination from such lubricant would be required to dominate the lipid distribution of this similarly organic-carbon-poor suite of samples.

Even though the lipid composition of Section 46254-2 shows several similarities to that of pipe dope, there are also significant differences (Table 3). From these data-in particular the absence of acyclic isoprenoid alkanes, diterpanes, and aromatic hydrocarbons in Section 462-54-2-we conclude that pipe dope is not a major contributor of lipids to the samples.

\section{Acyclic Components}

The $n$-alkanes form the major compound class of each section. $\mathrm{C}_{19}-\mathrm{C}_{35} n$-alkanes and the odd-over-even preference exhibited in the members having higher carbon numbers (most prominent in Section 462-54-2) are characteristic of higher plant waxes (Eglinton and Hamilton, 1967), and therefore suggest a significant terrestrial input to the sediments.

The absence of short-chain $n$-alkanes, particularly $n-\mathrm{C}_{17}$, a major component of phytoplankton (Oro et al., 1967; Blumer et al., 1971), pristane, and phytane, may reflect low productivity or extensive degradation in an oxic water column. Transport of the terrigenous $n$-alkane input by clay-mineral adsorption may have screened them from such degradation. Alternatively, the absence of short-chain $n$-alkanes could suggest loss by the migration of these more volatile components. The absence of squalane and other acyclic isoprenoids suggests that methanogenic bacteria have not been major contributors (cf. Brassell, Comet, et al., in press).

\section{Cyclic Components}

The absence of sterols, stanols, and sterenes-which are significant components of immature marine sediments (e.g., Brassell, Comet, et al., 1980b)-together with the presence of steranes, as both the natural $20 R$ and their diagenetically derived $20 S$ diastereoisomers (in

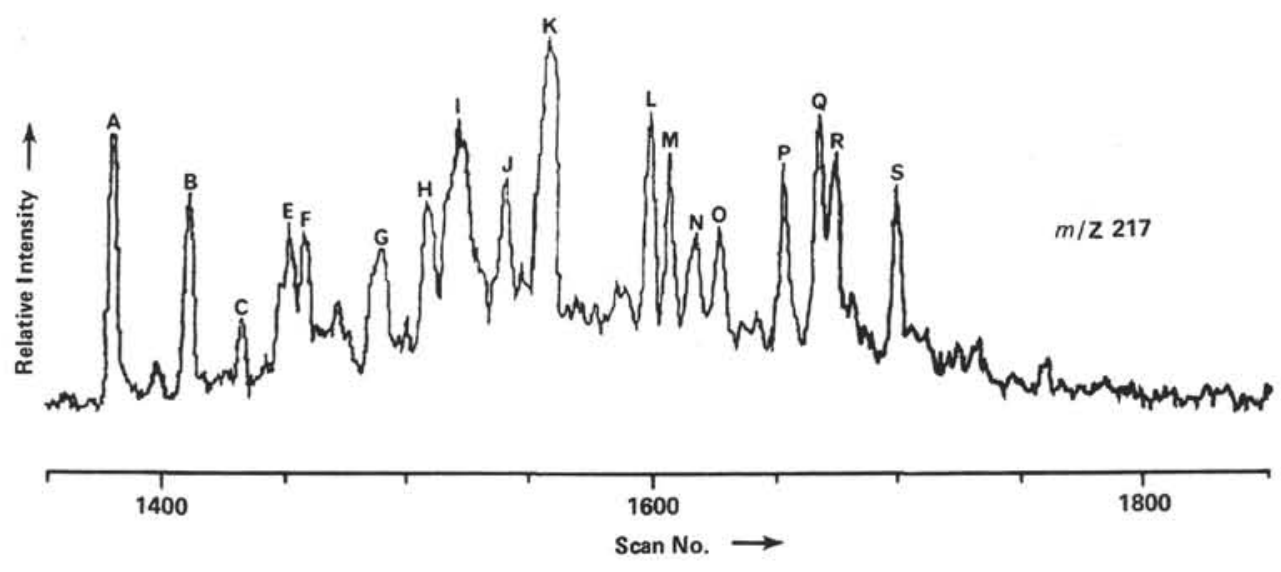

Figure 4. Partial mass fragmentogram of $m / z 217$ for Section 462-54-2. Labeled peaks correspond to the steranes and diasteranes listed in Table 2. (C-GC-MS conditions in "Experimental Methods," this chapter). 

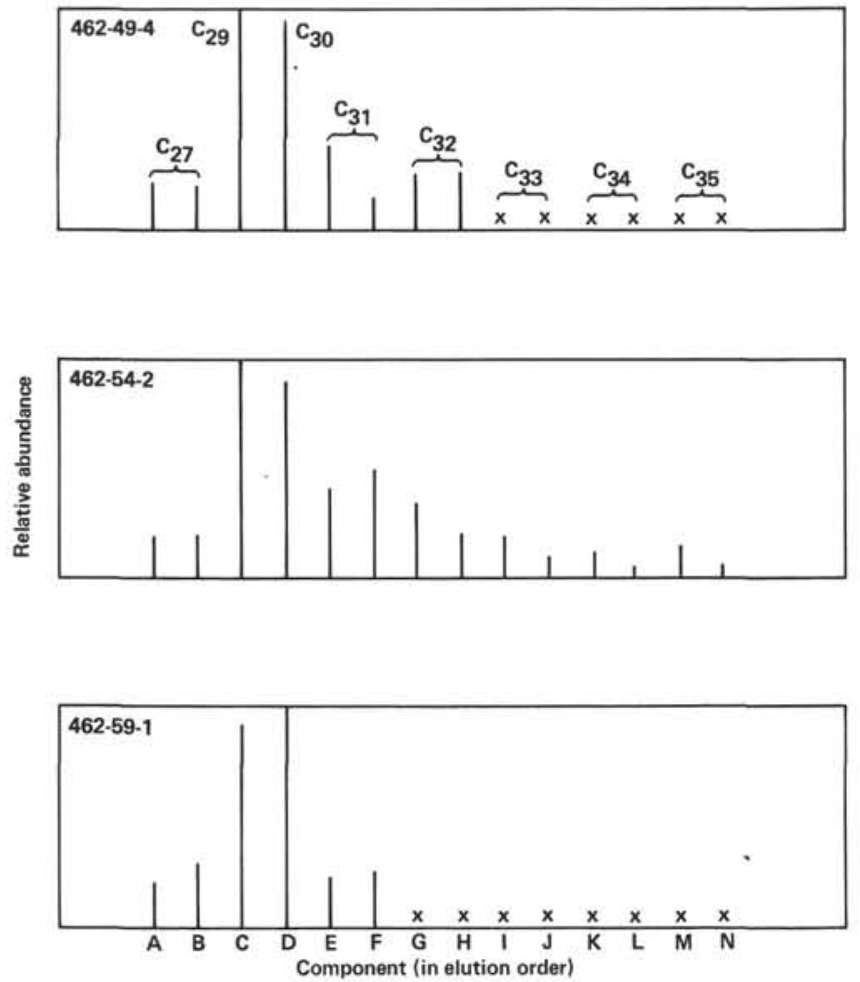

Figure 5. A. Distribution (in elution order) of hopanes in Sections 462-49-4, 462-54-2, and 462-59-1. Components are assigned as follows A, $18 \alpha-22,29,30$-trisnorneohopane (V); B, $17 \alpha-22,29,30$ trisnorhopane (VIa); C, $17 \alpha, 21 \beta$-30-norhopane (VIb); D, $17 \alpha, 21 \beta$ hopane (VIc); E, $22 S 17 \alpha, 21 \beta$-bishomohopane (VId); F, $22 R 17 \alpha$, $21 \beta$-homohopane (VId); G, 22S 17 $\alpha, 21 \beta$-bishomohopane (VIe); H, 22R $17 \alpha, 21 \beta$-bishomohopane (VIe); I, 22S $17 \alpha, 21 \beta$-trishomohopane (VIf); J, $22 R 17 \alpha, 21 \beta$-trishomohopane; K, $22 S 17 \alpha, 21 \beta$ tetrakishomohopane (VIg); L, $22 R 17 \alpha, 21 \beta$-tetrakishomohopane (VIg); M, 22R 17 $\alpha, 21 \beta$-pentakishomohopane (VIh); N, 22R $17 \alpha$, $21 \beta$-pentakishomohopane (VIh). $\mathrm{x}=$ not detected.

approximately a 1:1 ratio) and diasteranes, implies an advanced degree of maturity for the Nauru Basin lipids. Indeed, the stereochemical characteristics of the steranes and diasteranes in Section 462-54-2 resemble those of deeply buried samples $(>2400 \mathrm{~m})$, well within the zone of hydrocarbon generation in the Paris Basin (Mackenzie et al., in press). For example, $20 \mathrm{R}$ and $20 \mathrm{~S}$ 24-ethyl- $5 \alpha, 14 \beta, 17 \beta$-cholestanes (IV, $\mathrm{R}=\mathrm{C}_{2} \mathrm{H}_{5}$; components $\mathrm{Q}$ and $\mathrm{R}$ in Fig. 4 and Table 2) comprise about $73 \%$ of the total 24-ethylcholestanes (components P, Q, $\mathrm{R}$, and $\mathrm{S}$ ), which is similar to the values for the Courgivaux and Montmirail shales $(76 \%$ and $73 \%$, respectively) from the Paris Basin (Mackenzie et al., in press). The similar maturity of the steroidal components from the Nauru Basin at a shallower depth of burial (512 $\mathrm{m}$ sub-bottom) may, therefore, reflect the regional volcanism that took place between $\sim 110$ and $\sim 70$ m.y. ago and the resultant high geothermal gradients that affected these Cenomanian to Maestrichtian sediments (Site Summary and Schlanger and Premoli Silva, this volume).

$24 R$-ethylcholest-5-en- $3 \beta$-ol is known to be the major sterol of many higher plants, and has been used to infer a terrigenous input to marine sediments (Huang and
Meinschein, 1976). The 24-ethylcholestanes and 24ethyldiacholestanes, which account for about $60 \%$ of the total steroidal hydrocarbons detected in Section 462$54-2$, may be derived from $24 \mathrm{R}$-ethylcholest-5-en-3 $\beta$-ol (VII), and may therefore reflect a predominantly allochthonous terrestrial input. The absence of 4-methylsteroidal hydrocarbons, which may derive from the 4methylsterols of various organisms (e.g., dinoflagellates, Brassell, 1980; methanotrophic bacteria, Bird et al., 1971), contrasts with other Cretaceous DSDP sediments (Table 3) and also with the Toarcian shales of the Paris Basin (Ensminger, 1977).

The series of $17 \alpha, 21 \beta$-hopanes (VI), as both the natural $22 R$ and their diagenetic $22 S$ epimers, appear at a late stage in the maturation of sedimentary hopanes (Van Dorsselaer et al., 1977; Ensminger, 1977). 17 $\alpha$, $21 \beta$-hopanes are believed to be derived from their $17 \beta$, $21 \beta$ (VIII) counterparts by a clay-catalyzed diagenetic isomerization of the hopane compounds synthesized by bacteria (De Rosa et al., 1973; Rohmer and Ourisson, 1976); $17 \beta, 21 \beta$-hopanes are entirely isomerized to their more stable counterparts above the zone of hydrocarbon generation (Ensminger et al., 1977; Mackenzie et al., in press). Their absence in these samples is consistent with a mature sedimentary hopane distribution. The $22 S$ diastereoisomers comprise about $57 \%$ of the total extended $\left(>\mathrm{C}_{31}\right) 17 \alpha, 21 \beta$-hopanes (Appendix); this value is similar to the values $(50-65 \%)$ for deeper samples $(>2000 \mathrm{~m}$ ) from the Paris Basin (Ensminger et al., 1977; Mackenzie et al., in press). In the Nauru Basin, the maturity indicated by the hopane distributions is consistent with that inferred from the stereochemistry of the steroidal hydrocarbons.

Various organisms, including algae, ferns, and bacteria (Ensminger, 1977), are possible sources of $C_{30}$ hopanes and degraded $\left(<\mathrm{C}_{30}\right)$ hopanes. However, extended hopanes are thought to derive uniquely from the polyhydroxybacteriohopanes (Rohmer and Ourisson, 1976; Ourisson et al., 1979), and therefore suggest a bacterial input to the sediments.

\section{Influence of the Underlying Volcanic Complex}

Previous reports of thermal effects of intrusive basalt sills in the Kimmeridgian shales, Milnes Island, Greenland (Perregrand and Schiener, 1979) and Cape Verde Islands (Dow, 1978) suggest dramatic thermal alteration of organic matter within the proximity of roughly half the thickness of a sill, and a rapid decrease in such effects at increasing distance from the sill. Section $462-$ 59-1 lies 8 meters above the shallowest intrusive basalt sill, but comparison of the distributions of $n$-alkanes and hopanes common to all sections indicates that Section 462-59-1 has not experienced a significantly more severe thermal history than the two overlying samples. It appears, therefore, that the thermal effects of the volcanic complex are not markedly different throughout the sedimentary sequence examined herein (462-551 m sub-bottom depth; 97-8 $\mathrm{m}$ above the shallowest sill). The full extent of sediment maturation effected by the volcanic complex, in particular its influence on shallower horizons, cannot be fully assessed from the avail- 
Table 3. Semi-quantitative comparison of Section 462-54-2 with two other Cretaceous samples and with pipe dope.

\begin{tabular}{|c|c|c|c|c|}
\hline Section: & $462-54-2^{a}$ & $402 \mathrm{~A}-24-1^{\mathrm{b}}$ & $416 A-18-2^{c}$ & Pipe dope ${ }^{d}$ \\
\hline Location: & Nauru Basin & Bay of Biscay & Moroccan Basin & - \\
\hline $\begin{array}{l}\text { Chronostratigraphy } \\
\text { (depth in m): }\end{array}$ & $\begin{array}{l}\text { Campanian } \\
(512)\end{array}$ & $\begin{array}{l}\text { Lower Albian } \\
(360)\end{array}$ & $\begin{array}{l}\text { Valanginian } \\
(1266)\end{array}$ & 一 \\
\hline Lithology: & Marly limestone & $\begin{array}{l}\text { Carbonaceous marly } \\
\text { limestone }\end{array}$ & Turbidite & - \\
\hline \multicolumn{5}{|l|}{ Compound Class } \\
\hline$N$-alkanes & $\begin{array}{l}+++ \\
(\text { CPI } 1.3)^{e}\end{array}$ & $\stackrel{+++}{(\text { CPI } 1.4)^{f}}$ & $\stackrel{+++}{(\text { CPI 2.4 }})^{\mathrm{e}}$ & ++ \\
\hline Acyclic isoprenoids & n.d. & +++ & +++ & ++ \\
\hline Extended cyclic diterpanes & n.d. & n.d. & n.d. & ++ \\
\hline Diasterenes & n.d. & +++ & $++t$ & n.d. \\
\hline Steranes & ++ & + & ++ & ++ \\
\hline Diasteranes & ++ & n.d. & n.d. & ++ \\
\hline 4-Methylsteroidal hydrocarbons & n.d. & ++ & ++ & ++ \\
\hline$\alpha \beta$-Hopanes & +++ & + & + & ++ \\
\hline$\beta \beta$-Hopanes & n.d. & +++ & +++ & n.d. \\
\hline Aromatic hydrocarbons & n.d. & + & +++ & +++ \\
\hline "Hump" " & +++ & + & + & +++ \\
\hline
\end{tabular}

+++ major $10-100 \% ;++$ minor $1-10 \% ;+$ trace $<1 \%$, of major component, respectively.

n.d. = not detected.

a Data presented herein.

b Barnes et al., 1979, and Wardroper, 1979.

c Brassell, Comet, et al., in press (b).

d Brassell and Eglinton, in press.

e Range $\mathrm{C}_{22}-\mathrm{C}_{35}$.

${ }^{f}$ Range $\mathrm{C}_{16}-\mathrm{C}_{34}$.

able lipid data. The overall thickness of the mid-Cretaceous volcanic complex ( $>500 \mathrm{~m}$; Site Summary, this volume) suggests, however, that such alteration is probably extensive.

\section{Input Considerations}

An inconsistency in the neutral lipid fraction is the coexistence of an alkane "hump" and an odd-over-even preference in the long-chain $n$-alkanes. Such a combination of lipid characteristics suggests that they are not wholly indigenous but contain, in part, migrated components. The relative contributions of different sources to the lipid distribution are uncertain, but a signficant terrestrial source would seem to be indicated, with little evidence of an "algal" component.

\section{Comparison of Nauru Basin Lipids with Those of Other Cretaceous DSDP Samples}

The small amounts of lipids in Section 462-54-2 preclude detailed quantitative comparisons with Leg 48 and 50 samples; some comments can, however, be made (Table 3).

The lipids of the Nauru Basin are markedly more mature than those of the other cited samples, as indicated by the following:

1) CPI of $n$-alkanes.

2) Absence of alkenes (e.g., diasterenes, hopenes).

3) Sterane stereochemistry.

4) Predominance of $17 \alpha, 21 \beta$-hopanes over $17 \beta$, $21 \beta$-hopanes.

5) Absence of functionalized lipids (e.g., alkanols, alkanones, and alkanoic acids) found as minor components of the Leg 48 and Leg 50 samples (Wardroper, 1979; Brassell, 1980).

In summary, the Nauru Basin lipids are characteristic of mature sediments, in contrast to lipids of samples from the eastern North Atlantic, where immature lipid distributions have been recognized.

\section{CONCLUSIONS}

The three Upper Cretaceous samples contain low concentrations of organic material of mainly terrestrial origin. The apparent absence of organic material attributable to algal sources and the low organic carbon values probably reflect low productivity and oxic conditions in the water column. The predominance of hopanes over other polycyclic alkanes may imply extensive microbial activity and reworking of the organic matter. It is possible that the lipids are not wholly indigenous and may, in part, include migrated components.

Deposition of these Nauru Basin sediments occurred during the emplacement and growth of an off-ridge volcanic sill complex, but regional heating was never sufficient to obliterate the "magnetic stripe pattern" (Site Summary, this volume). The organic matter does, however, reflect this thermal episode. The lipid extracts are atypically mature for such shallow depths of burial (462-551 m sub-bottom), apparently lying within the oil window. Oil generation could therefore occur within the Nauru Basin, although it would be expected to be limited, owing to the small amounts of organic matter present in these samples. These data may be explained in terms of high paleotemperatures, although interpretation is complicated by the possible presence of migrated lipids.

\section{ACKNOWLEDGMENTS}

We thank the Natural Environment Research Council (GR3/2951 and supplement; GR3/3758, data acquisition) for support. J. M. and I. D. T. acknowledge Research Studentships from the Natural Environment Research Council and the Science Research Council, respectively. P. A. C. thanks the British Petroleum Co., Ltd. for financial support. We thank Mrs. A. P. Gowar and Mr. G. J. Shaw for 
assistance with C-GC-MS analyses and Mr. Martin West of the Microanalytical Laboratory, University of Bristol, for performing the organic carbon determinations. S. Schlanger, H. Jenkyns, and B. Simoneit reviewed the paper.

\section{REFERENCES}

Barnes, P. J., Brassell, S. C., Comet, P. A., et al., 1979. Preliminary lipid analyses of core Sections 18,24 , and 30 from Hole 402A. In Montadert, L., Roberts, D. G., et al., Init. Repts. DSDP, 48: Washington (U.S. Govt. Printing Office), 965-976.

Bird, C. W., Lynch, J. M., Pirt, S. J., et al., 1971. Steroids and squalene in Methylococcus capsulatus grown on methane. Nature, 230:473-475.

Blumer, M., Guillard, R. R. L., and Chase, T., 1971. Hydrocarbons of marine phytoplankton. Mar. Biol., 8:183-189.

Brassell, S. C., 1980. The lipids of deep sea sediments: their origin and fate in the Japan Trench [Ph.D. Thesis]. University of Bristol, U.K.

, 1980a. Preliminary lipid analyses of Cores 14,18 , and 28 from Deep Sea Drilling Project Hole 416A. In Lancelot, Y., Winterer, E. L., et al., Init. Repts. DSDP, 50: Washington (U.S. Govt. Printing Office), 647-664.

Brassell, S. C., Comet, P. A., Eglinton, G., et al., 1980b. Preliminary lipid analyses of Sections 440A-7-6, 440B-3-5, 440B-8-4, 440B-68-2, and 436-11-4: Legs 56 and 57, Deep Sea Drilling Project. In Scientific Party, Init. Repts. DSDP, 56, 57, Pt. 2: Washington (U.S. Govt. Printing Office), 1367-1390.

, in press. The origin and fate of lipids in the Japan Trench. In Douglas, A. G., and Maxwell, J. R. (Eds.), Advances in Organic Geochemistry 1979: Oxford (Pergamon Press).

Brassell, S. C., and Eglinton, G., in press. Organic geochemical studies of Sections 447A-10-2 and 448-1-1 from DSDP Leg 59. In Kroenke, L., Scott, R. B., et al., Init. Repts. DSDP, 59: Washington (U.S. Govt. Printing Office).

Brassell, S. C., Gowar, A. P., and Eglinton, G., in press. Computerised gas chromatography-mass spectrometry in analyses of sediments from the Deep Sea Drilling Project. In Douglas, A. G., and Maxwell, J. R. (Eds.), Advances in Organic Geochemistry 1979: Oxford (Pergamon Press).

De Rosa, M., Gambacorta, A., Minale, L., et al., 1973. Isoprenoids of Bacillus acidocaldarius. Phytochem., 12:1117.

Dow, W. G., 1977. Kerogen studies and geological interpretations. $J$. Geochem. Explor., 7:79-99.

Eglinton, G., and Hamilton, R. J., 1967. Leaf epicuticular waxes. Science, 156:1322-1335.

Ensminger, A., 1977. Evolution de composes polycyclique sédimentaires [Thèse de docteur en Sciences]. Universite Louis Pasteur, Strasbourg, France.

Ensminger, A., Albrecht, P., Ourisson, G., et al., 1977. Evolution of polycyclic alkanes under effect of burial (Early Toarcian shales, Paris Basin). In Campos, R., and Goni, J. (Eds.), Advances in Organic Geochemistry 1975: Madrid (ENADIMSA), pp. 375-391.

Huang, W.-Y., and Meinschein, W. G., 1976. Sterols as source indicators of organic materials in sediments. Geochim. Cosmochim. Acta, 40:323-330.

Mackenzie, A. S., Patience, R. L., Maxwell, J. R., et al., in press. Molecular parameters of maturation in the Toarcian shales, Paris Basin, France. I: Changes in the configurations of acyclic isoprenoid alkanes, steranes and triterpanes. Geochim. Cosmochim. Acta.

Oro, J., Tornabene, T. G., Nooner, D. W., et al., 1967. Aliphatic hydrocarbons and fatty acids of some marine and freshwater microorganisms. J. Bacteriol., 93:1811-1818.

Ourisson, G., Albrecht, P., and Rohmer, M., 1979. The hopanoids. The paleochemistry and biochemistry of a group of natural products. Pure Appl. Chem., 51:709-729.

Perregaard, J., and Schiener, E. J., 1979. Thermal alteration of sedimentary organic matter by a basalt intrusive (Kimmeridgian shales, Milnes Land, east Greenland). Chem. Geol., 27:331-343.
Rohmer, M., and Ourisson, G., 1976. Structure des bacteriohopanetetrols d'Acetobacter xylium. Tetrahedron Letts., pp. 3633-3636.

Seifert, W. K., and Moldowan, J. M., 1978. Applications of steranes, terpanes and Monoaromatics to the maturation, migration and source of crude oils. Geochim. Cosmochim. Acta, 42:77-92. 1979. The effect of biodegradation on steranes and terpanes in crude oils. Geochim. Cosmochim. Acta, 43:111-126.

Van Dorsselaer, A., Albrecht, P., and Connan, J., 1977. Changes in composition of polycyclic alkanes by thermal maturation (Yallourn Lignite, Australia). In Campos, R., and Goni, J. (Eds.), Advances in Organic Geochemistry 1975: Madrid (ENADIMSA), pp. 53-59.

Wardroper, A. M. K., 1979. Aspects of the geochemistry of polycyclic isoprenoids [Ph.D. Thesis]. University of Bristol, U.K.

Wardroper, A. M. K., Brooks, P. W., Humberston, M. J., et al., 1977. Analysis of steranes and triterpanes in geolipid extracts by automatic classification of mass spectra. Geochim. Cosmochim. Acta, $41: 499-510$.

\section{APPENDIX}

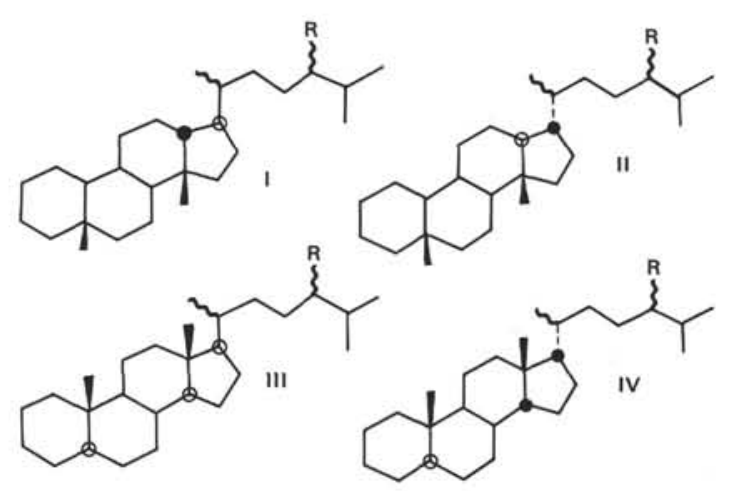

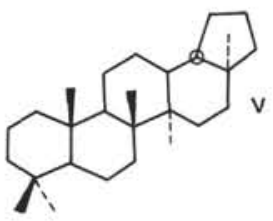

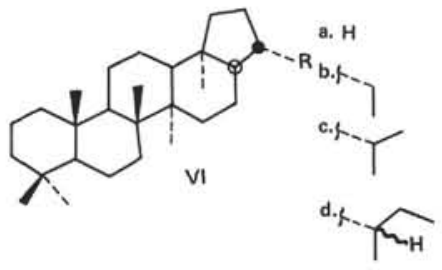<smiles>[C+]C(C)(C)CCC</smiles>

f.<smiles>[C]C(C)(C)[C@H](C)CCC</smiles><smiles>[C+]C(C)(C)CCCCC</smiles><smiles>[Y]C(C)(C)CCCCCC</smiles><smiles>CCC(CCC(C)[C@H]1CCC2C3CC=C4C[C@@H](O)CC[C@]4(C)C3CC[C@]21C)C(C)C</smiles>

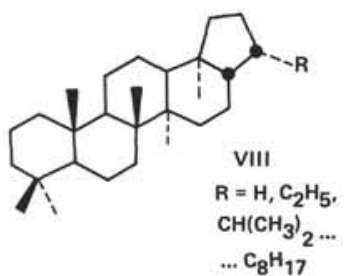

